\title{
NEW SPECIES OF WESTERN PLANTS.
}

T. S. BRANDEGEE.

Delphinium Purpusi, n. sp.-Perennial, slightly pubescent: stems somewhat leafy, $4-6^{\mathrm{dm}}$ high from a fibrous root: leaves $\mathrm{IO}^{\mathrm{em}}$ or less in diameter, 3 -cleft into incised or lobed mucronulate divisions on petioles $5^{-\mathrm{I}} 5^{\mathrm{cm}}$ long: raceme $5^{-\mathrm{I}} 5^{\mathrm{cm}}$ long, the few purplish red flowers on pedicels $\mathrm{I}-2^{\mathrm{cm}}$ long: spur thick and blunt, slightly curved, $\mathrm{I} 5^{\mathrm{mm}}$ long ; lateral petals $8-9^{\mathrm{mm}}$ long, the narrow laminæ yellow-bearded within; upper petals pale or white: sepals longer than the petals: follicles three, glabrous, reticulateveined, $2^{\mathrm{cm}}$ long: seeds $\mathrm{I}^{\mathrm{mm}}$ long, with a very loose cellular coating.

Erskine creek, southeastern California, Dr. C. A. Purpus, no. 5 OI 5 .

This species closely resembles $D$. mudicaule T. \& $G$. in its leaves, but has flowers of a quite different color, that dry to lavender rather than scarlet. The lateral petals are broader, bearded, and not so sharply laciniate; the upper petals are differently shaped, entire, broader, and shorter. $D$. mudicaule belongs to the northern part of California.

Cleomella gracilis, n. sp.-A glabrous strict annual: stems $3^{\mathrm{dm}}$ high, simple or sometimes with two short erect branches from near the base : the lowest leaves trifoliate; the others simple with flowering leafy branches $5^{\mathrm{mm}}$ long in their axils or the uppermost with single flowers; stipules simple or divided into filiform deciduous bristles: leaflets $\mathrm{I}-2^{\mathrm{cm}}$ long, $\mathrm{I}-\mathrm{I} .5^{\mathrm{mm}}$ wide, linear-spatulate, apiculate, on petioles $5^{\mathrm{mm}}$ long or less, often sessile: flowers yellow, with petals $2^{\mathrm{mm}}$ long equalling the stamens: capsule deltoid, $5^{\mathrm{mm}}$ wide, $4^{\mathrm{mm}}$ high on a curved pedicel $8^{\mathrm{mm}}$ long: stipe $\mathrm{I}^{\mathrm{mm}}$ long: seeds seven, blotched with purple, not tapering to the base, marked somewhat like those of C. plocasperma Wats.

Twin Springs, Nevada, Dr. C. A. Purpus, no. 6342. 
This may be an extreme form of $C$. parviflora Eng., but its strict habit gives it a very different appearance.

Glossopetalon pungens, n. sp.-Fruticose, cespitose, branching: stems $8-9^{\mathrm{cm}}$ high: leaves crowded, $7-8^{\mathrm{mm}}$ long, slightly short-hirsute, the margins, midrib, and 3-6 veins strongly thickened, alternate, narrowly oblong-elliptical, attenuate to each end and tipped with a spine $\mathrm{I}^{\mathrm{mm}}$ long: flowers terminating the stems or short branchlets on pedicels $3-4^{\mathrm{mm}}$ long that bear three or four scarious bracts similar to the leaves but smaller: calyx of five broadly ovate bracts; $4^{\mathrm{mm}}$ long, with denticulate margins, two or three of them spinose tipped, and the others acuminate: petals five, obovate-lanceolate, narrowed to the base, $7-8^{\mathrm{mm}}$ long, $2^{\mathrm{mm}}$ wide: the five stamens inserted with the petals as long as the calyx, the five opposite the calyx a third longer and with wider filaments : carpels two or three, pubescent, ovate, attenuate to the stigma, sessile upon the disk: ovules in each carpel two, collateral and ascending, inserted on the ventral suture above the base of the cell : fruit a firm coriaceous follicle equalling the calyx, opening along the ventral suture, usually one-seeded.

Sheep mountains, Nevada, growing on rocks at 4000-5000 feet elevation, Dr. C. A. Purpus, no. 6I 3 I.

This is a most interesting species, and may throw some light upon the true position of the genus in classification. It is so distinct from the other species, that the generic characters have been somewhat included in its description so as to exhibit more certainly its affinity. The original species G. spinescens was collected by Mr. Wright near Frontera, New Mexico, and since then has been often found between western Colorado and eastern California. Dr. Gray, in the original diagnosis, thought the genus intermediate between Celastraceæ and Staphyleaceæ, and later with the description of an additional closely related species, G. Nevadense, refers it confidently to Staphyleaceæ, and adds: " as in the original specimens of G. spinescens, so in these, although seeds seem to be full-grown and well formed, I do not find a single developed embryo. If this should be straight and the albumen wanting, I should refer the genus to Rosaceæ near to Purshia; but I expect it will turn out otherwise." This newly discovered species was collected in abundance, with plenty of full grown and well-formed seeds exactly like those of the other two species, but unfortunately it resembles them also in having no embryos. Among the recent collections of $G$. Nevadense, however, some 
mature seeds containing embryos have been found, and from them it is seen that it is slender, cylindrical, curved into a half circle, $3^{\mathrm{mm}}$ in length, incumbent, the radicle about as long and nearly as broad as the cotyledons, inferior; testa brown, coriaceous; albumen fleshy, rather copious. G. pungens usually has two follicles, sometimes three or by abortion one. Here it is interesting to note that the other species do not have their solitary follicles inserted on the center of the disk. The stigma is somewhat lateral, and in G.pungens more decidedly so. The generic description of Glossopetalon will have to be slightly amended so as to include this plant, but the additional characters derived from the new form and from mature seed seem only to strengthen its anomalous position.

A fourth species G. meionandrum Koehne, ${ }^{x}$ collected in the Gunnison region, Colorado, by Dr. Purpus, has been added to the genus.

Horkelia (Ivesia) mutabilis, n. sp.- Stems several, $3^{\mathrm{dm}}$ high, erect, branched above, villous, leafy: stipules ovate-lanceolate, acute, $5-7^{\mathrm{mm}}$ long; basal leaves numerous, $\mathrm{I} 2-2 \mathrm{O}^{\mathrm{cm}}$ long, silkyhirsute, pinnate, leaflets fifty or less, sessile, more or less imbricated, $2-5^{\mathrm{mm}}$ long, usually divided to the base into obovateoblong pointed segments: cyme much branched, many-flowered, open : disk $4^{\mathrm{mm}}$ in diameter: bractlets triangular-lanceolate, half as long as the broadly triangular-lanceolate sepals : petals yellow, exceeding the bractlet but not as long as the sepals, narrowly lanceolate-obovate, acute : stamens five; filaments filiform, $2^{\mathrm{mm}}$ long: styles two to seven; akenes few and usually mottled.

Table and Charleston mountains, Nevada, and Pine valley mountains, Utah, Dr. C. A. Purpus, nos. 6195, 6079, 6381.

The anthers in some of the specimens are purple.

PURPUSIA, n. gen.-Caly $\mathrm{x}$ tube elongated, tubular, widening above; lobes five, valvate; bractlets none: petals five: stamens five, opposite the sepals; filaments filiform; anthers didymous: disk lining the calyx tube and thickened at the base: carpels six or seven on a stipitate receptacle; styles nearly terminal, filiform, articulate at base; embryo somewhat curved ; cotyledons broadly oblong, about four times the length of the small inflexed superior radicle: akenes attached laterally slightly above their base: leaves alternate, imparipinnate; stipules adnate to base of petiole: stems erect: inflorescence corymbosely racemose.

${ }^{\mathrm{x}}$ Gartenflora $43: 237$. 
This genus is related to Potentilla and Chamærhodos. From Potentilla it differs in having a long calyx tube and no bractlets, and from Chamærodos in its terminal style and the position of the stamens, and it is distinct from both in its peculiar stipitate receptacle.

Purpusia saxosa, n. sp.-Perennial from a stout root, I0-I $5^{\mathrm{cm}}$ high, hirsute and somewhat viscid: basal leaves numerous, pinnate; leaflets two or three pairs, the lowest pair on pedicels $5^{\mathrm{mm}}$ long, irregularly oblong or orbicular, IO- $5^{\mathrm{mm}}$ in diameter, more or less deeply cut into five to ten rounded entire or incised lobes; stem leaves similar, becoming simple and bract-like above, their stipules $7^{\mathrm{mm}}$ long, ovate-acuminate, entire or incised: stem branched above, bearing solitary flowers in the axils of the leaves, forming a leafy paniculate cyme: flowers on pedicels I- $2^{\mathrm{cm}}$ long, exceeding the bracts: calyx tube $3^{\mathrm{mm}}$ long, indistinctly ten-ribbed; lobes $4^{\mathrm{mm}}$ long, lanceolate-acuminate: petals white, $4^{\mathrm{mm}}$ long, $\mathrm{I}^{\mathrm{mm}}$ wide, slightly acuminate, inserted, opposite the sinuses: anthers $\mathrm{I}^{\mathrm{mm}}$ long, equaling the filaments : receptacle hirsute, no broader than the gynophore, which is $2^{\mathrm{mm}}$ long, pubescent and narrowly cylindrical: styles $2^{\mathrm{mm}}$ long: akenes smooth.

Sheep mountains, Nevada, at 4000-5000 feet altitude, Dr. C. A. Purpus, no. 6r 34.

Chamebatia Foliolosa Benth. var. australis, n. var.-Much less glandular-pubescent than the type: leaves narrower in outline, three times as long as wide and barely more than twice pinnate: calyx lobes shorter: ovary smooth.

La Grulla, Lower California, C. R. Orcutt in 1886; Mt. San Miguel near San Diego, D. Cleveland; and reported by Mr. Orcutt from Point Loma near the ocean.

Typical $C$. foliolosa is more northern in its range and growsat considerable altitudes in the Sierra Nevada, so that it is somewhat surprising to find a form so far south and near the sea level.

Boykinia Purpusi, n. sp.-Slender and smooth except the upper part of the glandular stem, $20-25^{\mathrm{cm}}$ high : leaves roundreniform, the largest $4^{\mathrm{cm}}$ wide, with five to seven acutely incised lobes; petioles $6-7^{\mathrm{cm}}$ long or less, with ramentaceous bristles at 
their dilated bases: the paniculate cyme $8-\mathrm{IO}^{\mathrm{cm}}$ long, secund: petals white, $3^{\mathrm{mm}}$ long, twice the length of the lanceolate-triangular sepals: stamens five, or sometimes perhaps abnormally seven, with filaments $0.5^{\mathrm{mm}}$ long.

On moist rocks in Black cañon of the Uncompahgre river, Colorado, at an elevation of $7200 \mathrm{ft}$, Dr. C. A. Purpus, no. $5 \mathrm{I} 2$.

The specimens are young and have no mature fruit.

Mentzelia leucophylla, n. sp.-Biennial or triennial (?) : stems several from the root, $3-4^{\mathrm{dm}}$ high, covered with a soft white pubescence : radical leaves $6-8^{\mathrm{cm}}$ long and $\mathrm{I}^{\mathrm{cm}}$ wide, linearoblong, attenuate to the base and apex, regularly sinuate-dentate, densely covered on both surfaces with short rigid hairs, upwardly barbed, those of the margin minutely glochidiate; stem leaves oblong, $4^{\mathrm{cm}}$ long, $\mathrm{I}-\mathrm{I} .5^{\mathrm{cm}}$ wide, rounded at the top and pointed, cordate-clasping at base especially the upper ones, slightly sinuate-dentate, densely hispid, only the marginal hairs glochidiate: flowers bright yellow, on pedicels $\mathrm{I}-8^{\mathrm{mm}}$ long, in a sparingly divaricately branched panicle: petals broadly spatulate, slightly retuse and pubescent at tip, $\mathrm{I}^{\mathrm{cm}}$ long: sepals triangular acuminate, obtuse, $6^{\mathrm{mm}}$ long: outer stamens broadly petaloid, the blades slightly dentate above: capsule $8-10^{\mathrm{mm}}$ long and nearly as broad: seeds flat, margined by a border less than $0.5^{\mathrm{mm}}$ wide.

Ash Meadows, Nevada, Dr. C. A. Purpus, no. 6032.

Aplopappus (Stenotus) MacLeanii, n. sp.-Cespitose from a multicipital caudex, the woody stems $6-12^{\mathrm{cm}}$ long, sending down rootlets: leaves $2^{\mathrm{cm}}$ long and less than $\mathrm{I}^{\mathrm{mm}}$ wide, crowded on branchlets $2-3^{\mathrm{cm}}$ long, linear-lanceolate with stout midrib and ciliate with short stiff hairs: peduncles $2^{\mathrm{em}}$ long, terminating the branchlets, bearing two bracts similar to the leaves and a single head about $8^{\mathrm{mm}}$ high and wide: involucral bracts linearlanceolate, minutely glandular-ciliate : rays six to eight, shortly lobed at tip, $2^{\mathrm{em}}$ long: disk flowers twenty to twenty-five; styles dark margined, with long conical tips: pappus soft and 
white, of numerous bristles nearly as long as the corolla : akenes short, hirsute.

Near Dawson, Northwest Territory, Fohn MacLean, in 1898.

This plant is nearest $A$. stenophyllus Gray, but is easily distinguished from it by the more condensed habit and the short acute ciliate leaves.

Eriophyllum aureum, n. sp.--Annual, whitened with close cottony wool, much branched from the base, the usually simple, monocephalous stems $4^{\mathrm{cm}}$ high, leafy : cauline leaves $5-8^{\mathrm{mm}}$ long, alternate, oblong-spatulate, obtuse, narrowed at the base; radical ones broader and sometimes slightly lobed: heads barely exceeding the leaves, $6^{\mathrm{mm}}$ high, forty to fifty-flowered: involucre of about ten narrowly ovate acuminate separate scales: flowers golden yellow; the rays oblong, with a truncate retuse very slightly five or six-lobed tip; disk flowers equalling the involucre, funnel-form, bullate-rugose; style tips conical; appendages of the anthers narrowly linear or subulate: pappus a crown of about six very minute denticulate scales of different widths: akenes linear-clavate, nearly smooth: receptacle convex, the height about twice the width, smooth.

Lone Pine, California, T. S. Brandegee, April I6, i89i.

The numerous golden-yellow flowers contrasting with the very white cottony stems and leaves, and the habit of forming hemispherical tufts make this a very showy species.

Eriophyllum Congdoni, n. sp.-Annual, $\mathrm{I}-2^{\mathrm{em}}$ high, whitened with loose cottony wool: stems branched from about the middle, monocephalous: lower leaves few, spatulate, sometimes two or three-toothed above, attenuate into a petiole; upper leaves mostly entire, sessile, lanceolate-spatulate: heads $7-10^{\mathrm{mm}}$ high, forty to fifty-flowered, on peduncles $4-5^{\mathrm{cm}}$ long: involucre of eight or nine oblong-acuminate distinct scales, thickened at the center and base: rays yellow, about eight, broadly elliptical, entire or slightly retuse at tip: disk corollas equalling the involucres, funnel-form with a rather long cylindrical tube, nearly glabrous: style tips almost truncate: anther appendages broadly 
ovate: akenes $3^{\mathrm{mm}}$ long, linear-clavate, hirsute; pappus of the disk akenes $1.5-2^{\mathrm{mm}}$ long, the longer scales narrow, the shorter ones wider and more laciniate; pappus of the ray akenes shorter and similar: receptacle convex, higher than wide, smooth.

"Mountains near Hennessy's, Mariposa county," California, May 1894 .

Received from Mr. J. W. Congdon under the name of E. mubigenum Greene.

Eriophyllum paleaceum, n. sp.--Annual, whitened with loose cottony wool, IO-I $2^{\mathrm{cm}}$ high, with many monocephalous branches: leaves $\mathrm{I}-\mathrm{I} .5^{\mathrm{cm}}$ long, linear-spatulate, the lower somewhat attenuate into a petiole and often two or three-lobed or dentate about the tip : involucre of eight narrow acuminate scales, distinct to the base: heads $6-8^{\mathrm{mm}}$ high, forty to fifty-flowered, on peduncles $2-3^{\mathrm{cm}}$ long: rays six or seven, yellow, narrowly elliptical, $7^{\mathrm{mm}}$ long, very slightly two or three-lobed at tips: disk flowers $3^{\mathrm{mm}}$ long, equaling the involucre, funnel-form with a short cylindrical pubescent tube: style tips short-conical; appendages to the anthers narrowly ovate: akenes $2.5^{\mathrm{mm}}$ long, linear-clavate, rounded at the top, hirsute; pappus a crown of minute denticulate scales: receptacle conical, twice as high as broad, paleceous especially about the apex where half a dozen persistent linear scales become $\mathrm{I}^{\mathrm{mm}}$ long.

Kernville, California, May I4, I892, and Olancha, California, May I89ı, T. S. Brandegee; also in the mountains of Tulare county, California, Dr. C. A. Purpus.

Laphamia intricata, n. sp.- Puberulent and slightly pubescent above ; intricately much branched from a woody root, I5$20^{\mathrm{cm}}$ high, the numerous stems each bearing two to six heads on peduncles $0.5^{-2^{\mathrm{cm}}}$ long: leaves nearly all alternate, linear, 5$8^{\mathrm{mm}}$ long, obtuse, dilated above to $\mathrm{I}^{\mathrm{mm}}$ wide, somewhat hispid: bracts of the involucre $3^{\mathrm{mm}}$ long, linear, with thin margins especially the inner ones, the acute tips more pubescent, midrib thickened: ray flowers none; disk flowers about thirty, bright yellow, with glandular pubescent tube: pappus wanting: akenes hirsute and slightly ciliate. 
Pahrump and on Sheep mountain, Nevada, on rocks, Dr. C. A. Purpus, nos. 605 I and 6r 34 .

Laphamia fastigiata, n. sp.--Scabrous puberulent, cespitose from a woody root: stems $\mathrm{IO}-\mathrm{I} 4^{\mathrm{cm}}$ high, the short branches monocephalous: lower leaves opposite, spatulate, attenuate into a margined petiole, entire to trifid, $2-3^{\mathrm{cm}}$ long ; stem leaves smaller, with short petioles, $3-4^{\mathrm{mm}}$ wide, cuneate at base and trifid above, the central lobe much the longest: involucre of about fifteen linear acute slightly hispid-pubescent bracts that are carinate thickened at the base : rays none : disk flowers about forty, light yellow, $5^{\mathrm{mm}}$ long, equaling the involucre; tube pubescent: pappus a single delicate awn, half the length of the corolla or less, sometimes wanting: akenes slightly ciliate on the margins.

Sheep mountain, Nevada, Dr. C. A. Purpus, no. 6r 42.

Gilia sedifolia, n. sp.-Glandular-pubescent except the lower leaves : stem simple, thick and fleshy from a stout biennial root: leaves crowded near the base, fleshy, linear-spatulate, obtuse, sessile, entire, $\mathrm{I}^{\mathrm{cm}}$ long, the upper ones becoming smaller and bract-like: peduncles $12^{\mathrm{mm}}$ long or less, rarely two-flowered, solitary from the axils of the lower leaves or crowded in those of the bracts from the middle of the stem upwards: calyx $4^{\mathrm{mm}}$ long, its triangular-acuminate lobes equaling the violet corolla: tube of the corolla as long as its ovate not spreading lobes: stamens inserted in the sinuses, shorter than the corolla lobes: style $3^{\mathrm{mm}}$ long: capsule as long as the calyx, about fifteenseeded: seeds not developing spiricles when wetted, decidedly wing-margined.

Uncompahgre range, Colorado, at $12,000 \mathrm{ft}$. altitude, Dr. C. A. Purpus, no.697.

An abundance of old leaves persists about the base of the stem, giving it the appearance of a perennial, although it can only be a biennial. Flowers are borne sparingly in the axils of the lower leaves, but are crowded throughout the upper half, completely hiding the small bracts. The thick fleshy leaves recall those of some sedums.

Phacelia Purpusi, n. sp.-Annual, 2-3 $3^{\mathrm{dm}}$ high, somewhat 
branching, hispid-hirsute and glandular-viscid above: leaves ovate, acuminate or obtuse, entire, $2-6^{\mathrm{cm}}$ long including the petiole, the smaller ones tapering to a sessile base : racemes or spikes $5-10^{\mathrm{cm}}$ long, secund, dense; pedicels $\mathrm{I}-2^{\mathrm{mm}}$ long: corolla violet, broadly open campanulate, slightly exceeding the spatulate-obovate unequal-calyx lobes; appendages salient, long, united at base of the stamen; stamens sparingly bearded at base, exserted beyond the corolla lobes: style long exserted, cleft to below the middle: capsule hirsute, broadly ovate, pointed, half as long as the calyx lobes: ovules two to four to each placenta; seeds regular, turgid at maturity, not angled, dark brown, deeply favose, a iittle more than $\mathrm{I}^{\mathrm{mm}}$ long.

Sequoia Mills, California, T. S. Brandegee; also Middle Tule river, California, Dr. C. A. Purpus, no. 5603.

Young plants collected by J. W. Congdon at Sherlock, Mariposa county, California, June 15,1898 , probably belong to this species. It is apparently nearest $P$. circinatiformis Gray.

Allocarya salsa, n. sp.-Annual, rough-hispid throughout, prostrate-spreading $\mathrm{I}-2^{\mathrm{dm}}$ in diameter, with rather few stout, often inflated leafy branches simple or branched toward the ends: leaves broadly linear, pustulate-hispid, otherwise glabrous : bracts similar, longer than the calyxes of the dense spikes: flowers sessile : calyx clavate, the elongated lobes widely spreading: corolla $4^{\mathrm{mm}}$ long, with spreading lobes and white inconspicuous processes: nutlets glabrous, $2^{\mathrm{mm}}$ long, lanceolate, unsymmetrical, longitudinally rugose on the unequal inner faces, transversely rugose on the back; scar of attachment nearly basal, small on the three caducous nutlets, the fourth attached by a broad surface and probably separating only by decay,

Alkaline soil, Twin springs, Nevada, Dr. C. A. Purpus, no. 6339, August 1898 .

In aspect unlike any other species known to me.

Cryptanthe excavata, n. sp.- Annual, I-2 ${ }^{\mathrm{dm}}$ high, rather sparingTy hirsute-hispid, branching from the base, branches slender, flexuous: fruiting spikes usually in threes and flowers 
at length remote: calyx $2-3^{\mathrm{mm}}$ long, yellowish-setose, slightly elongating in fruit, not appressed to the rachis, strongly gibbous from the horizontal development of the solitary nutlet: corolla $4-5^{\mathrm{mm}}$ long and the spreading lobes quite as broad, throat nearly closed by the prominent white processes: nutlets lanceolate, light brown, $2-5^{\mathrm{mm}}$ long, rather sharply angled, recurved at the tip, minutely tessellate and with scattered papillæ; groove triangular, excavated, a little more than one third as long as the nutlet.

Stites, Colusa county, and also in adjacent Lake county, California, T. S. Brandegee, April I 892.

Cryptanthe costata, n. sp.-Annual, $0.5^{-2^{\mathrm{dm}}}$ high, erect, rigid, branching from the base, appressed-pubescent and pilose-hispid; the inflorescence hispid and bracteate throughout: leaves narrowly lanceolate, widest at base, $2-3^{\mathrm{cm}}$ long : bracts nearly as long as the rather dense fruiting calyxes: flowers $2^{\mathrm{mm}}$ long, scarcely spreading, constricted below the white processes: fruiting calyxes about $5^{\mathrm{mm}}$ long, the slender costate segments erect persistent and not spreading: nutlets four, minutely and irregularly rugose, sharply thin-margined, the three smaller a little more than $\mathrm{I}^{\mathrm{mm}}$ long, the fourth larger and more persistent, the ventral face triangular-lanecolate, the groove of the same shape, open quite to the base.

Borregos springs, Colorado desert, T. S. Brandegee, April I8, I895.

In appearance it is somewhat intermediate between $C$. angustifolia and C. crassisepala, At maturity it is of a shining straw color, and quite conspicuous on account of the glistening setæ of the large persistent calyxes.

Cryptanthe Ramosissima Greene. Dr. Rose, working with additional material collected by Dr. Palmer, ${ }^{2}$ has corrected errors of the earlier descriptions, and noting the second nutlet often developed records his opinion that $K$.ramosissima and $K$. maritima are too nearly related. This opinion seems to be fully justified, for the only means of separating them seems to be by their habitat, the mainland forms passing usually as Krynitzkia or

${ }^{2}$ Proc. U. S. Nat. Mus. I I : 532. 
Cryptanthe ramosissima, while the island plants are named $K$. or $C$. maritima. They vary much in habit, apparently being able to adapt themselves to very diverse conditions. All the forms that I possess have one peculiarity that separates them sharply from all other species of Cryptanthe, even from C. Cedrosensis, namely, they have only two ovules! The numerous specimens examined range in habitat from Inyo county, the Mohave and Colorado deserts, to northern Lower California and Lagoon head, and the many islands off the coast of Upper and Lower California from Santa Catalina to Santa Margarita.

Penstemon floridus, n. sp.-Glabrous and glandless, $3^{-4 m}$ high : leaves thin-coriaceous, $5-7^{\mathrm{cm}}$ long, ovate-lanceolate, sessile, acutely spinulose dentate or the smaller oblong and shortpetioled, none connate-perfoliate: thyrsus virgate, $3^{\mathrm{dm}}$ long; peduncles and pedicels $\mathrm{I}-2^{\mathrm{cm}}$ long or shorter: corolla rosepurple, $2-2.5^{\mathrm{cm}}$ long: sepals ovate-acuminate, $4^{\mathrm{mm}}$ long; the tube of the corolla two to three times as long, then dilated into a ventricose throat and slightly contracted at the mouth, lobes somewhat spreading: sterile filament glabrous; anthers explanate: capsule three times as long as the sepals, broadly ovate: seeds black, irregular in form, obtusely angled, rugose and granular.

Mt. Magruder, Nevada, Dr. C. A. Purpus, no. 5928.

This plant is nearly related to $P$. spectabilis, a species given that name by Dr. Thurber, who collected it in southern California. Dr. Gray included with it plants from the Interior Basin, but the above described species seems to be quite distinct. Some of the differences between it and P. spectabilis are the absence of connate-perfoliate leaves, the more virgate thyrsus, the corollas with somewhat constricted mouth and short lobes not widely spreading. P. spectabilis is a common species of western San Diego county, California.

Pentstemon incertus, n. sp.-Suffrutescent, $3-4^{\mathrm{dm}}$ high, much branched from the base, glabrous excepting the slightly glandular peduncles and pedicels : leaves narrowly linear-lanceolate, $2-4^{\mathrm{em}}$ long, $2^{\mathrm{mm}}$ wide, the lowest shorter: sepals ovate, acuminate, $5^{\mathrm{mm}}$ long: corolla distinctly bilabiate, violet (?) fading to lavender, $2.5^{\mathrm{em}}$ long, with a broad tube twice the length of the sepals, then 
dilated into a 'ventricose throat; lower lip deeply three-lobed and spreading, rarely sparingly yellow-bearded: sterile filament densely yellow-bearded above the middle.

Walker pass and sandy slopes of Argus mountains, California. Dr. C. A. Purpus, nos. 535 I, 5346.

This species is near $P$. fruticiformis Coville, but is easily distinguished by its narrower leaves and differently shaped flowers; also its calyx lobes are not white-margined, and usually the corolla lobes are not bearded. The flower of $P$. fruticiformis has almost no proper tube, while that of $P$. incertus is two or three times the length of the sepals, and the throat is not so ventricose, nor the lobes so spreading. When dried the flowers of $P$. incertus become a dark lavender, while those of $P$. fruticiformis change to ochroleucous.

Pentstemon petiolatus, n. sp.-Glabrous, the calyx slightly pruinose: stems $\mathrm{IO}^{\mathrm{cm}}$ high, cespitose from a woody root: leaves coriaceous, sharply serrate, broadly ovate, acuminate, $\mathrm{I}-2^{\mathrm{cm}}$ long and broad, cordate to cuneate at base, on petioles IO- $5^{\mathrm{mm}}$ long: the leafless thyrsus short, $2-4^{\mathrm{cm}}$ long, 5 to I 2 -flowered; bracts ovate-acuminate, $\mathrm{I}-3^{\mathrm{min}}$ long: sepals ovate, acuminate, $6^{\mathrm{mm}}$ long: corolla $\mathrm{I}^{\mathrm{mm}}$ long, broadly funnelform, the short lobes spreading. the lower bearded within: sterile filament glabrous: capsule slightly exceeding the sepals, nearly as broad as long: seeds dark-colored, granular roughened and almost wing-angled.

Sheep mountain, Nevada, at $5000 \mathrm{ft}$. altitude, Dr. C. A. Purpus, no. 6 I 36.

Dr. Purpus notes that the flowers were violet. Nearest to P. deustus Dougl., which has longer and narrower usually sessile leaves, and smaller flowers in a virgate leafy thyrsus.

Pentstemon (Saccanthera) Purpusi, n. sp.-Densely soft pubescent and somewhat glandular above: stems ascending from a woody base $6-15^{\mathrm{cm}}$ high: leaves orbicular or broadly obovate, tapering to a short petiole or sessile, $8-10^{\mathrm{mm}}$ wide, entire or rarely slightly crenate-dentate: thyrsus half the length of the stems; cymes short-pedunculate, one to three-flowered: corolla $3-3 \cdot 5^{\mathrm{cm}}$ long, violet, ventricose at the throat and not enlarged above, upper lip $5^{\mathrm{mm}}$ long, lobed to the middle, lower lip the same length, three-lobed: sepals $7-8^{\mathrm{mm}}$ long, ovate-acuminate or broadly 
linear: sterile filament glabrous; anthers short-ciliate along the line of dehiscence and bearing a few long woolly hairs near the filament: capsule longer than the sepals; seeds gray, irregularly cubical, sharply angled, $\mathrm{I}-2^{\mathrm{mm}}$ long, the surface slightly pitted.

Snow mountain, California, above $7000 \mathrm{ft}$. altitude, Dr. C. A. Purpus, July I 894 , nos. I I 57, I 259.

The dark purple stems, sepals, and bracts, with the bright violet flowers serve to make this one of the handsome species.

Pentstemon Røzli Regel var. violaceus, n. var.-Puberulent below and short pubescent above, not glandular and but slightly viscous about the calyx: stems numerous from a woody root, $\mathrm{I} 5^{\mathrm{em}}$ high : thyrsus narrow and corolla little ampliate, dark violet: seeds irregular in shape, somewhat rugose, slightly pitted, smooth upon the larger face: capsule longer than the calyx,

Oriental, Gold mountain, Nevada, Dr. C. A. Purpus, no. 5995.

The purple stems and calyx and dark violet corollas give to the broad clumps of this species a pleasing effect.

Abronia alpina, n. sp.-Perennial (?), prostrate-spreading, forming mats about $20^{\mathrm{cm}}$ in diameter, viscid-pubescent: leaves orbicular or slightly elongated, $3-5^{\mathrm{mm}}$ in diameter, on petioles IO- $15^{\mathrm{mm}}$ long: involucres on peduncles $5-6^{\mathrm{mm}}$ long, divided to the base into four or five narrowly ovate acuminate bracts $2-3^{\mathrm{mm}}$ long, about five-flowered: perianth rose-colored to white, I $2-15^{\mathrm{mm}}$ long, salverform with narrow tube; the short lobes deeply obcordate, spreading to $8-9^{\mathrm{mm}}$ wide: fruit $3-4^{\mathrm{mm}}$ long, narrowed to both ends, thin coriaceous, obtusely or acutely fiveangled, glabrous, tuberculate-veiny.

In Monatchy meadows of Mt. Whitney, at an elevation of 7000-8000 ft., and at Templeton near the craters, growing in loose granite sand, Dr. C. A. Purpus, nos. I877, 1497.

An exceedingly handsome compact species, bearing so many flowers that the leaves are nearly hidden.

Eriogonum formosum, n. sp. (E. giganteum Wats. var. formosum K. Brandg. ${ }^{3}$ ) - Sometimes but not commonly branching from the base: leaves densely white-tomentose on both sides, more or

${ }^{3}$ Erythea $5: 79$. 
less glabrate above in age, oblong-lanceolate or oblanceolate, $5-8^{\mathrm{em}}$ long, $\mathrm{I}-2^{\mathrm{em}}$ wide, on stout petioles $2-4^{\mathrm{cm}}$ long: cyme broad, ramose, foliaceous-bracted, on a peduncle $2^{\mathrm{dm}}$ or more long, ultimate branchlets white-tomentose as well as hairy: involucres clavate, rather narrow, with short broad scarious-margined teeth, $4-5^{\mathrm{mm}}$ long, tapering into a pedicel of about the same length, many-flowered: perianth rose-colored, about $4^{\mathrm{mm}}$ long, segments somewhat appressed-hairy with prominent midrib, the outer ones obovate cucullate, the inner longer and tapering into a marginal claw: akene nearly as long as the flower, triquetrous above.

E. molle Greene may be maintained as a species by its habit, which is quite different from E. giganteum. It is not at all arborescent and bears its few-branched cymes on stout peduncles $6-10^{\mathrm{dm}}$ long. In our garden it flowers nearly the whole year and bloomed, as probably all the perennial species do under favorable circumstances, the first year from seed. All the parts of the flower are about one half larger than those of E. giganteum, and the branches of the cyme are very dense, almost capitate. The pedicels of the perianth are not at all exserted in either of these species.

Eriogonum Purpusi, n. sp.- Perennial from a branching caudex, the stems densely matted and very short: leaves whitetomentose on both sides, oval to oblanceolate, $3-5^{\mathrm{mm}}$ long; petiole longer than the blade, dilated below, glabrate on both surfaces but tomentose on the margins: scapes $1-1.5^{\mathrm{dm}}$ high, lanate at base, glabrous and wiry above: inflorescence a capitulum of six to ten involucres, six to ten-bracteate at base, the inner ones also bracteate: involucres cylindrical-turbinate, about $3^{\mathrm{mm}}$ long; segments with a thickened glabrous center, margined and united by their scarious portions, which are lightly floccose without and within, and in age give way to the base at the sinuses: perianth glabrous, white with reddish midvein, much exserted, spreading or reflexed, truncate at base; outer seg. ments ovate, exceeded by the oblong inner ones: filaments nearly glabrous: akene obtusely triangular, equalling the perianth, scabrous especially on the angles.

Argus mountains, California, about $5000 \mathrm{ft}$. altitude, Dr. C. A. Purpus, June I897, no. 5484 .

San Diego, Cal. 


\section{$2 \mathrm{BHL}$ Biodiversity Heritage Library}

Brandegee, Townshend Stith. 1899. "New Species of Western Plants." Botanical gazette 27(6), 444-457. https://doi.org/10.1086/327855.

View This Item Online: $\underline{\text { https://www.biodiversitylibrary.org/item/94861 }}$

DOI: https://doi.org/10.1086/327855

Permalink: https://www.biodiversitylibrary.org/partpdf/222975

\section{Holding Institution}

Missouri Botanical Garden, Peter H. Raven Library

\section{Sponsored by}

Missouri Botanical Garden

\section{Copyright \& Reuse}

Copyright Status: Public domain. The BHL considers that this work is no longer under copyright protection.

This document was created from content at the Biodiversity Heritage Library, the world's largest open access digital library for biodiversity literature and archives. Visit BHL at https://www.biodiversitylibrary.org. 